\title{
Income distribution, the Great Depression, and the relative income hypothesis
}

\author{
Christian A. Belabed* \\ Foreign Research Division, Oesterreichische Nationalbank, Vienna, Austria
}

This paper discusses the rise of top-end inequality and its effects on household consumption, saving, and debt in the United States during the 1920s by applying a non-standard theory of consumption, the relative income hypothesis, to the period of interest. Analysing the relevant data descriptively, the paper argues that income inequality is linked to the increase of household consumption and the simultaneous decline of household savings as well as rapidly increasing household debt. Thus, the rise of top-end inequality in connection with a broader institutional change, such as the deregulation of financial markets, has contributed to a build-up of financial and macroeconomic instability in the period leading to the Great Depression.

Keywords: income distribution, relative income hypothesis, household debt, financial innovation, Great Depression

JEL codes: D31, D33, E21, E25, N12, N22, N32, N62

\section{INTRODUCTION}

'Of the tendencies that are harmful to sound economics, the most seductive, and in my opinion the most poisonous, is to focus on questions of distribution.' (Lucas 2004)

The view that income distribution may affect aggregate demand as well as macroeconomic stability has received renewed interest by economists (for example, Rajan 2010 and Reich 2010; also, Atkinson/Morelli 2011 and van Treeck 2014 provided surveys on the topic). Rajan (2010) famously argued that income inequality can be identified as one underlying cause of the current financial and economic crisis. The political response, Rajan (ibid.: 9) argues,

was to expand lending to households, especially low-income ones. The benefits - growing consumption and more jobs - were immediate, whereas paying the inevitable bill could be postponed into the future. Cynical as it may seem, easy credit has been used as a palliative throughout history by governments that are unable to address the deeper anxieties of the middle class directly. ... But

* The views expressed in this paper are strictly those of the author and in no way represent those of the Oesterreichische Nationalbank (OeNB) or the Eurosystem. This paper is part of my doctoral thesis and received financial support from the Macroeconomic Policy Institute (IMK), for which I am grateful, before starting the position at the Oesterreichische Nationalbank. I would like to thank staff at the Macroeconomic Policy Institute in Düsseldorf for comments during various stages of this research. I would also like to thank participants at the research seminar of the Institute for Political Economy Berlin, the FMM conference 2014 in Berlin, the conference on 'Large-scale crises: 1929 vs. 2008' at the Università Politecnica delle Marche in Ancona, participants of the doctoral colloquium at JKU Linz and the editor of this journal for very helpful comments. The usual disclaimer applies, so all remaining errors are mine. Email: christianalexander.belabed@oenb.at

Received 8 September 2015, accepted 23 September 2016 
when easy money pushed by a deep-pocketed government comes into contact with the profit motive of a sophisticated, competitive, and amoral financial sector, a deep fault line develops.

Turning to the Great Depression period, Galbraith (2009), for instance, described five fundamental weaknesses of the economic and financial system at that time and mentions the 'bad distribution of income' as the first of all factors that contributed to the Great Depression. In a similar way, Marriner S. Eccles, the former chairman of the Federal Reserve Bank, wrote that 'as in a poker game where the chips were concentrated in fewer and fewer hands, the other fellows could stay in the game only by borrowing. When their credit ran out, the game stopped' (Eccles 1951: 76). However, the influence of rising income inequality on household consumption behavior in the 1920s has never been studied. Hence, this paper asks whether a rise of top-end income inequality may have contributed to the buildup of macroeconomic and financial instability in the United States during the 1920s, ultimately setting the stage for the Great Depression. The core of the paper is the application of the relative income hypothesis of Duesenberry (1949) to the relevant data on consumption, savings, and debt for the US during the 1920s. The main point is that the relative income hypothesis provides a very useful view on the link between income distribution and macroeconomic and financial instability for the US during the 1920s by emphasizing the role of status comparisons between households and the demand of households for credit as well as higher spending out of a given income to finance additional consumption expenditures. The application of the relative income hypothesis to the United States during the 1920s is, to the best of our knowledge, the first attempt to explain developments in income inequality, household saving, and debt, as well as the build-up of macroeconomic and financial instability in the US during the 1920s.

Despite the anecdotal evidence mentioned above, the mainstream of the economics profession exclusively studied either the onset of the Great Depression or the impact of economic policy on the recovery after $1933 .{ }^{1}$ This may be due to the standard representative-agent model, which rules out any effect of rising inequality on other households' consumption. Post-Keynesian economists such as Kaldor (1966) and Kalecki (1954), on the other hand, have long studied the effects of rising income inequality (although exclusively the functional income distribution) on aggregate demand and growth but never applied their abstract theory to the Great Depression era. In its essence, the argument of Keynes (1936 [2008]) was that an upward redistribution of income or a decline in labor's share of total income has a dampening effect on aggregate consumption due to a higher propensity to save of higher income groups. This view continues to be the conventional wisdom among post-Keynesian economists, although some authors have recently incorporated inter-household income distribution into theoretical models (for example, Belabed et al. 2013; Kapeller/Schütz 2014; 2015; Palley 2010). Obviously, this expected decline in consumption did not materialize in the US as there was a consumption boom accompanied by a housing boom and a stock market boom during the 1920s. Hence, the distinction between functional and personal income distribution is particularly important for the analysis of the effects on aggregate demand and represents another novel feature of this paper. During the 1920 s, the wage share has been rather constant, whereas top income shares have increased considerably during this period. Theories based on the

1. See Cole/Ohanian $(1999 ; 2000 ; 2004)$ and Cole et al. (2005) for standard neoclassical accounts; Friedman/Schwartz (1963) for a monetarist approach; Eggertsson (2008; 2012) and Romer (1990; 1992; 1993) as well as Bernanke (2000) for the New Keynesian school. Temin (1994; 1989; 1976b) as well as Kindleberger (1986) and Kindleberger/Aliber (2005) provide excellent accounts on the international aspects of the Great Depression. Temin (1976a) criticizes the monetarist approach where policy mistakes of the central bank caused the Depression of the 1930s. 
functional distribution of income, such as underconsumption theories in the tradition of Hobson (1909) and Malthus (1820), predict stagnating aggregate consumption expenditures. According to these authors, the propensity to save of workers is negligible whereas capitalists save a substantial fraction of their income. Hence, a decline of the wage share leads to insufficient aggregate demand and over-saving. ${ }^{2}$ However, this is clearly at odds with empirical evidence from the 1920s when the share of national income going to labor was rather flat. The pattern of household consumption of the 1920s, in particular consumer durable goods, can hardly be explained without a close look at the distribution of incomes between households, which is another novel feature of this paper.

Another important issue concerns the institutional environment, such as financial market innovation and deregulation. There is evidence that financial deregulation and innovation has taken place in the 1920s, which enabled households to purchase durable goods or invest in housing by making use of consumer credit or mortgages. Furthermore, changes in societal attitudes towards consumer credit changed considerably, as did advertising and marketing techniques (Olney 1991). The effect of the former was an increased demand for credit, whereas the latter dramatically expanded the circle of peers with which households were able to compare themselves, which is the central feature of the relative income hypothesis.

The remainder of the paper is structured as follows. Section 2 reviews the relevant literature. Section 3.1 presents data on rising inequality in the 1920s, followed by Section 3.2 which presents stylized facts on the structure of consumption expenditures as well as household saving and debt. Section 4 presents descriptive evidence on financial innovation and the change of institutions during the 1920s. Section 5 concludes.

\section{REVIEW OF THE LITERATURE}

\subsection{Comparative analyses of the Great Depression and the Great Recession}

There is a large body of literature on the Great Depression which renders any attempt to present a representative picture an ambitious endeavor. Of the more recent attempts, some studies highlight the parallels between the Great Recession and the Great Depression. For instance, Almunia et al. (2010) provide a comprehensive account of parallels between the two crises with particular importance given to the international scope of both crises and to the effectiveness of policy responses in the 1930s. Bordo/James (2009) examine three analogies between the two crises. First, they discuss macroeconomic analogies with an exclusive focus on monetary policy. Second, microeconomic issues such as bank regulation and the reorganization of banking. Finally, global issues such as imbalances in trade and capital flows between countries. However, the most striking parallel is almost never mentioned in these studies: the rise of income inequality in the period preceding each crisis. This seems to be a serious shortcoming, as the literature neglects important information on how macroeconomic and financial instability is built up.

\subsection{Literature on the Great Depression}

One of the most influential contributions of that time was the 'debt-deflation theory' of Fisher (1933). He argued that the downturn of a normal business cycle can turn into a depression if over-indebtedness and deflation are simultaneously involved. By 1933,

2. For a neat and comprehensive account of underconsumption theories (and theorists), the reader is referred to Bleaney (1976). 
efforts to liquidate debt, which reduced the nominal value by about 20 percent, were more than offset by an increase in the dollar of 75 percent such that 'real debt, that is the debt measured in terms of commodities, was increased about 40 percent' (ibid.: 346). Hence, all efforts to liquidate debt have merely resulted in raising the real levels of debt, which led to further liquidation of debt and so on. Fisher's theory is a convincing explanation for how a recession can turn into a depression, but it is not an explanation for why household indebtedness increases to unprecedented levels in the first place. Consequently, his policy prescriptions focus predominantly on reflating the price level to avoid a debt-deflation spiral and not on preventing the build-up of private credit bubbles.

Another line of argument stresses the importance of changes in household balance sheets. Mishkin (1978) argued convincingly that conventional explanations of the Great Depression do not take into account changes in household balance sheets and are, thus, not appropriate in explaining the sharp drop in aggregate demand, especially for durable consumption goods and residential housing, after 1929. Households have built up unprecedented amounts of debt prior to the Depression to finance the purchase of durable consumption goods. The real value of household liabilities has, in the wake of the slump of 1929, increased by 20 percent from 1929 to 1930. During times of serious financial distress, households want to reduce their debt by deleveraging. However, imperfect capital markets for tangible assets render the chance to turn these assets into cash (to service debt) or borrow against them almost impossible unless households accept significant losses when trying to liquidize assets. In Mishkin's (1978: 925) words, 'the opportunity cost of holding tangible assets, such as consumer durables or housing, increases substantially when a consumer gets into financial trouble. Therefore, as the probability of financial distress increases for the consumer, he will lower his demand for tangible assets. ${ }^{3}$ Koo (2009) essentially argues in the same direction but focuses on the firm and banking sector. His analysis highlights the problem of insufficient credit demand due to a change in firms' sector behavior from profit-maximizing to debt-minimizing. As important as these contributions are to understanding the course of the Depression from 1929 onwards, they do not explain the driving factors behind the observed balance-sheet problems. In particular, no role is given to the unprecedented rise in income inequality before the Great Depression, let alone possible systematic interconnections between inequality, consumption, saving, and debt.

Exactly this point was taken up recently by Kumhof et al. $(2012$; 2015) in two innovative contributions. In both papers, financial crises can arise endogenously as a result of a sharp increase in income inequality in the periods preceding the current financial and economic crisis and the Great Depression of the 1930s. In their models, an upward redistribution of income leads to an increased supply of credit to bottom- and middle-income households, which readily increase their indebtedness to finance consumption expenditures in periods of stagnating, or even falling, wages. Given the nature of their model, the developments in household debt are supply-side-determined, which is not entirely convincing. The narrative developed here suggests that there is a reason to believe that households' demand for credit changed once the implications from the relative income hypothesis are seriously taken into account. Societal attitudes towards credit, as Olney (1991) argued, may have reinforced the demand for credit to finance additional consumption expenditures.

Some studies, exceptionally, have argued in favor of the income inequality view of the Great Depression. For instance, Brown (1997) studies the effects of consumer credit on

3. Olney (1999) argued in a similar direction by pointing out that households in financial distress postpone spending on durable consumer goods in order to avoid default. 
the propensity to consume of a society. Not surprisingly, an increased availability of demand for credit relaxes the household budget constraint and, as Brown (1997: 622) argues, 'reacts on the propensity to consume in much the same way as a (downward) redistribution of income would - that is, by raising the spending power of low- and moderateincome households. ${ }^{4}$ Via unsustainable indebtedness of low- and moderate-income households, the increased use of credit to finance consumption expenditures creates the seed for financial and macroeconomic instability. However, widened credit availability does not necessarily mean an increased demand for credit by households. Another point missing in Brown (1997) is households' saving behavior. As was argued before, the Keynesian consumption theory cannot explain the decline in households' saving rate in the context of rising inequality. It follows that if households finance consumption expenditures by drawing down savings and engage in deficit spending, it would be interesting to know why they do so. The application of the relative income hypothesis provides a convincing explanation for household behavior in the 1920s, and this is exactly what distinguishes this paper from Brown (1997).

\subsection{Literature on the relative income hypothesis}

One important application of the relative income hypothesis is Frank et al. (2014), who develop an 'expenditure cascades model' based on the relative income hypothesis to explain the co-emergence of declining savings rates and rising top-end income inequality. In their model, households include preferences over the consumption habits of their social peers. As a result of upward-looking status comparisons, it follows that the optimal saving rate of each household decreases with the total consumption of their social peers and increases with their own income, as households face a trade-off between a painful loss of status if they do not increase their consumption expenditures correspondingly. ${ }^{5}$ However, there is no need to assume that this concerns only luxury goods, as one example, drawn from Frank et al. (2014), may clarify. Because the quality of schools in the US largely depends on local property taxes, which in turn depend on real-estate prices, households may opt to move to more expensive neighborhoods in order to avoid sending their offspring to below-average schools. The results will be twofold. First, households draw down their savings and, second, they use credit to engage in deficit spending if their own income is not high enough to cover additional expenses. ${ }^{6}$ Precisely this mechanism was formally modeled by Belabed et al. (2013) for the period preceding the current

4. The underlying consumption theory is based on Keynes (1936 [2008]) and states that an upward redistribution of income exerts downward pressure on aggregate demand as consumption is likely to fall due to the smaller propensity to consume out of income of the higher echelons in the income distribution. Keynes (1939: 129), in a clarifying comment, famously argued that '[s]ince I regard the individual propensity to consume as being (normally) such as to leave a wider gap between income and consumption as income increases, it naturally follows that the collective propensity for a community as a whole may depend (inter alia) on the distribution of income within it.'.

5. For empirical evidence on upward-looking status comparisons and the effect on household consumption, see Bertrand/Morse (2013), Christen/Morgan (2005), and Drechsel-Grau/Schmid (2014).

6. To be precise, Reich (2010) mentions labor supply as a third coping mechanism with which households may react to stagnating or decreasing incomes. Households can either choose to work longer hours or other members of the household, typically women, start participating in the labor market. However, to analyse whether this was the case during the 1920s is beyond the scope of this paper and the connection between increased labor supply and macroeconomic and financial instability is, most likely, negligible. 
financial and economic crisis and confirmed by Behringer/van Treeck (2013) using panel econometric estimations for the G7 countries and a larger sample of 20 countries, controlling for a standard set of explanatory variables.

The present paper argues that households in the 1920s behaved in the way described above. To finance additional expenditures for goods such as cars, TV and radio sets, or housing, households drew down savings and increased their debt. In order to make sense of what happened to household consumption, saving, and debt during the 1920s, this paper argues in favor of the relative income hypothesis of Duesenberry (1949), which predicts that the consumption of households will be positively related to the consumption of a social reference group. Under upward-looking status comparisons and a specific institutional environment such as financial market innovation, rising top-end inequality gives rise to 'expenditure cascades' and a fall in the aggregate saving rate, accompanied by a rise in household debt. Debt-financed consumption emulation was made possible by financial market deregulation and financial innovation. Securitization of installment credit or mortgages was at the forefront of financial innovation.

\section{STYLIZED FACTS AND THE RELATIVE INCOME HYPOTHESIS: THE US DURING THE 1920s}

This section discusses descriptive evidence on income inequality as well as household consumption, saving, and debt during the 1920s and concludes with an application of the relative income hypothesis to the data at hand for the US during the 1920s. Data on top-end income inequality comes from the World Wealth and Income Database, which collects data on income from tax records for a number of countries, including the US, in a way that enables the creation of long-run time series. However, income data based on tax records most likely underestimate the dispersion of income at the top of the income distribution as households with high income are likely to report lower income to avoid tax payments even though the data are subject to various corrections and comparisons, such as Pareto interpolation. In addition, fundamental concepts such as the definition of income, tax units, or households may vary over time and, hence, influence the comparability of the data over time. ${ }^{7}$ Data on household consumption, saving, and debt comes from various sources. Unfortunately, a consistent system of national accounts for the US is not yet available for the time preceding 1929. However, this paper uses the most often quoted and used data to ensure that its conclusions are based on the most reliable data available (see also Table 1). ${ }^{8}$ The most significant shortcoming of the data at hand is the lack of disaggregated data on household consumption, savings, and debt, which considerably limits the depth of this study as we cannot infer conclusions on the consumption and saving behavior of various parts of the income distribution. However, the developments of rising top-end income inequality coupled with the developments in (aggregate) household consumption, savings, and debt are compatible only with the relative income hypothesis and provide sufficient evidence for the relevance of including social norms in consumption theories and taking the institutional framework that allows for credit-driven consumption growth.

7. For details on the database and its shortcomings, the reader is referred to the homepage available at: http://www.wid.world.

8. Goldsmith (1955), for instance, still constitutes one of the most comprehensive and widely cited sources on household saving, while Carter et al. (2006) is the outcome of one of the most ambitious and important projects regarding data collection for the US from colonial times. 
Table 1 Series names and sources

\begin{tabular}{ll}
\hline Series name & Source \\
\hline $\begin{array}{l}\text { World Top Income Shares } \\
\text { Household debt as percentage of disposable } \\
\text { personal income }\end{array}$ & World Top Incomes Database \\
$\begin{array}{l}\text { Disposable personal income } \\
\text { Employee compensation }\end{array}$ & IMF (2012: fig. 3.9) \\
Gross domestic product & Goldsmith (1955: table N-1) \\
& Kuznets (1937: table 4) \\
Expenditures on goods and services; personal & Carter et al. (2006: table \\
savings rate & Ca9-19) \\
Housing units started (privately owned, non-farm) & Olney (1991: table 2.8) \\
& Carter et al. (2006: table \\
$\begin{array}{l}\text { Nominal home prices } \\
\text { Total short-term consumer debt }\end{array}$ & Dc510-530) \\
$\begin{array}{l}\text { Consumer non-mortgage debt } \\
\text { Total non-farm residential mortgage debt }\end{array}$ & Goldsmith (1955: table D-1) \\
$\begin{array}{l}\text { Mortgage debt-to-wealth ratio } \\
\text { Finance income as percentage of GDP (various } \\
\text { measures) }\end{array}$ & Olney (1991: table 4.1) \\
$\begin{array}{l}\text { Compensation in finance, insurance, and real } \\
\text { estate as a share of aggregate compensation }\end{array}$ & Grebler et al. (1956: table L-1) \\
\hline & Philippon (2015) \\
\hline
\end{tabular}

One of the novelties of this paper is that the data mentioned above have, to the best of our knowledge, never been used in conjunction with the relative income hypothesis in order to provide a new explanation for the Great Depression. In other words it enables economists and economic historians to paint a different picture of the onset of the Great Depression as well as its depth and length.?

\subsection{The rise of income inequality}

The following section discusses evidence on both dimensions of income inequality, the personal and functional distribution of income, in the decade prior to the Great Depression. We argue that the rise in income inequality observed in the period of interest and the decline of household saving rates and indebtedness is consistent with the expenditure cascade model of Frank et al. (2014). The theoretical link between income inequality and increased financial fragility, measured by household indebtedness, is the relative income hypothesis of Duesenberry (1949), which states that household preferences over consumption are interdependent such that an increase in consumption of the very top households in the income distribution translates into a desire for higher consumption of the households just below the very top, and so on (see Section 3.3). ${ }^{10}$

9. See Jordà et al. $(2013 ; 2015)$ for a discussion of different types of crises. They argue that crises which were preceded by credit-driven housing bubbles constitute the most severe type of financial crisis, ultimately causing more severe and longer recessions.

10. In fact, the idea that household consumption depends on the consumption expenditures of other households goes back to Veblen (1899 [2007]: 71): 'the standard of expenditure which commonly guides our efforts is not the average, ordinary expenditure already achieved; it is an ideal of 


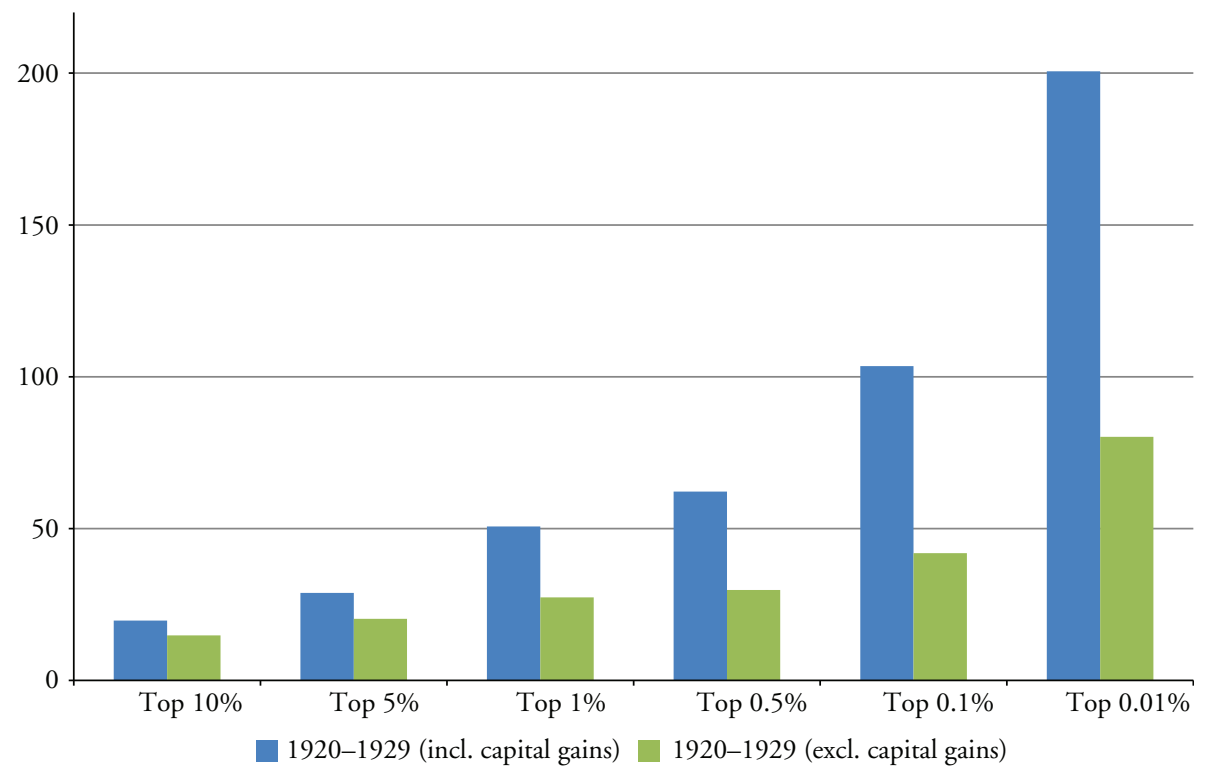

Source: World Top Incomes Database.

Figure 1 Growth of top income shares between 1920 and 1929 (including and excluding capital gains)

Figure 1 presents the growth of top income shares, including and excluding capital gains, between 1920 and 1929 for various parts of the top income distribution. Despite the observable rise in income inequality in the 1920s, one striking feature stands out. The growth of top income shares was more pronounced the further up the income distribution one looks, so that growth cascades are observable. For instance, whereas the share going to the top decile increased by around 20 percent, the income share going to the very affluent - the top 0.01 percent - increased by around 200 percent. However, there are large differences between the growth rates of top income shares when subtracting capital gains. The increase of the income share for the top decile including capital gains is only marginally larger than the respective income share excluding capital gains, whereas more than half of the increase of the 0.01 percent's share of income is attributable to capital gains during the 1920s.

Figure 2 shows the top income shares and household debt in percent of GDP for the 12 years before the Great Depression. Top income shares increased significantly in this rather short period and peaked just before the onset of the Depression. In 1928, the

consumption that lies just beyond our reach, or to reach which requires some strain. The motive is emulation - the stimulus of an invidious comparison which prompts us to outdo those with whom we are in the habit of classing ourselves. ... [O]ur standard of decency in expenditure ... is set by the usage of those next above us in reputability ....' In some way, Veblen even anticipated expenditure cascades when noting that '[t]he leisure class stands at the head of the social structure in point of reputability; and its manner of life and its standards of worth therefore afford the norm of reputability for the community. ... In modern civilized communities the lines of demarcation between social classes have grown vague and transient, and wherever this happens the norm of reputability imposed by the upper class extends its coercive influence with but slight hindrance down through the social structure to the lowest strata' (ibid.: 59). 


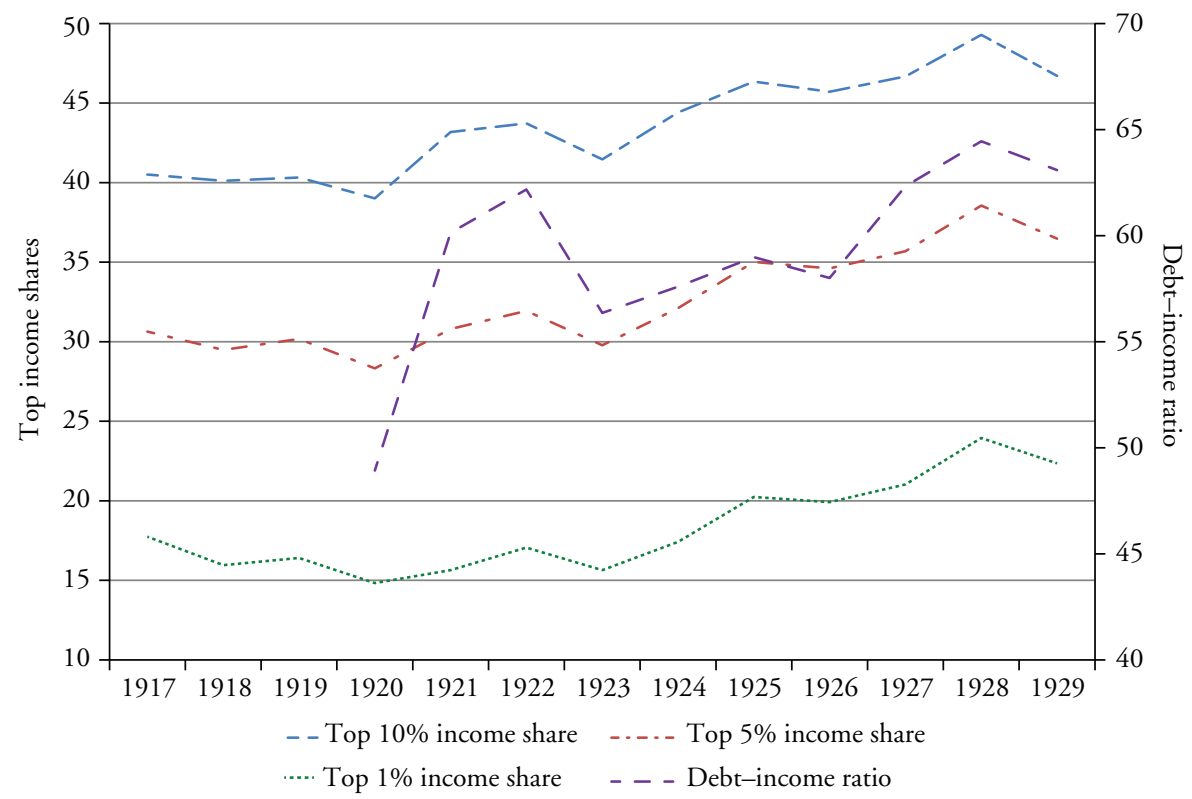

Sources: World Top Incomes Database; IMF (2012: fig. 3.9).

Figure 2 Top income shares (including capital gains) and household debt as percentage of disposable personal income, 1917-1929

top 10 percent of the population, earned almost half of total income. The top 5 percent took home a still relatively large 40 percent of total household income, and the top 1 percent earned almost a quarter of all household income. One possible reason for the observed increase of income inequality is the decrease of top marginal tax rates for income and inheritances. The top marginal income tax rate decreased from 73 percent in 1919 to 24 percent in 1929. Additionally, during the same period, the top marginal inheritance tax rate decreased from 25 percent to 20 percent (with a short-lived increase to 40 percent in 1926). ${ }^{11}$ This is particularly interesting because, as Piketty (2014) mentions, the wage share of the top decile increased from 26.7 percent in 1919 to 29.2 percent in 1929. In addition, the wage share of the top percentile rose from 7.4 percent to 8.7 percent during the same period. Historical data of the Internal Revenue Service (IRS) also reveal that although reported total income has increased from $\$ 19.8$ billion to $\$ 26.7$ billion between 1919 and 1929 , the total tax liability decreased from $\$ 1.3$ billion to $\$ 1$ billion (the trough of total tax liability was reached in 1923 with a mere $\$ 662$ million). Concomitantly, household debt as a share of GDP peaked in 1928 around 65 percent of GDP, an unprecedented level of household indebtedness.

At the same time, the wage share, measured here as employment compensation and disposable personal income in percent of GDP, have remained essentially flat during

11. All data are taken from Piketty (2014), available here: http://piketty.pse.ens.fr/en/capital21c2. Note that the top inheritance tax rate in 2013 is a whopping 35 percent compared to 1929 , and the top marginal income tax rate, as of 2013 , is still 40 percent. 


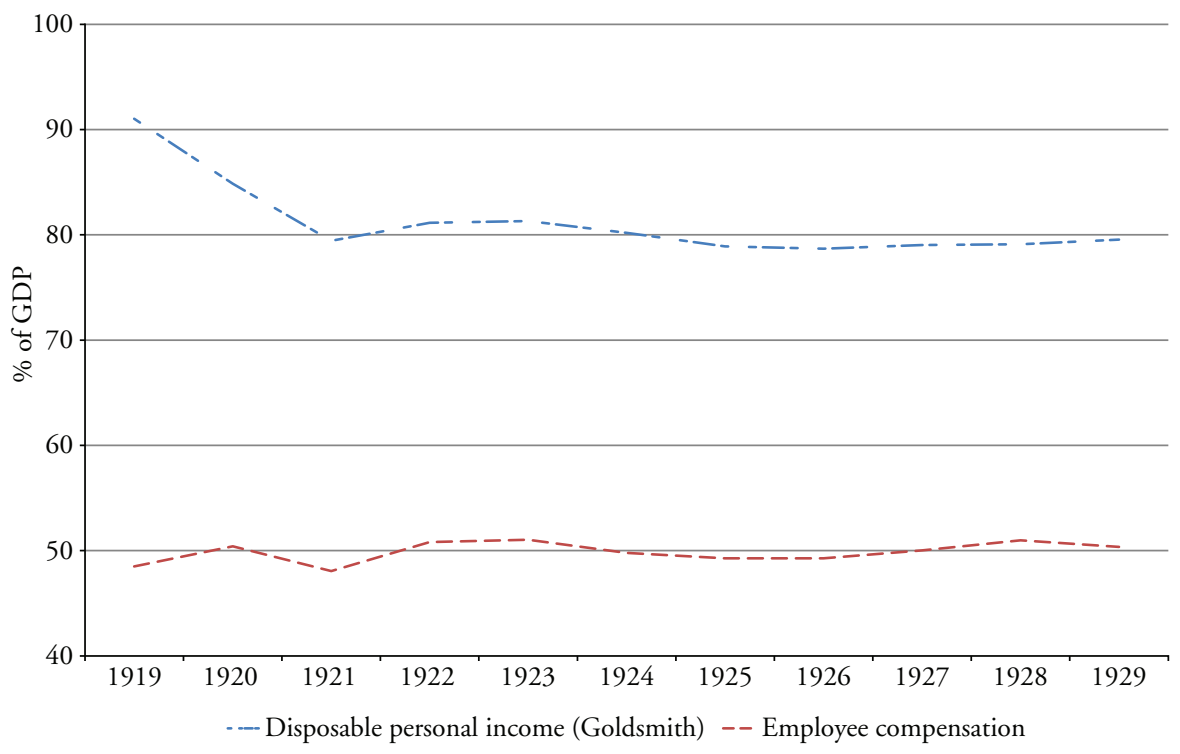

Sources: Carter et al. (2006: table Ca9-19); Goldsmith (1955: 427, table N-1); Kuznets (1937: table 4).

Figure 3 GDP income approach - disposable personal income and employee compensation as percentage of GDP, 1919-1929

the 1920s, as Figure 3 shows. Between 1920 and 1929, wages as a share of GDP have not moved at all, which is rather puzzling, as we would expect wages to rise during boom times. Simultaneously, disposable personal income remained flat as well. It is now obvious that the consumption boom of the 1920s cannot be attributed to rising wages or disposable income as a share of GDP. ${ }^{12}$ In addition, average weekly earnings in manufacturing, for instance, have not grown considerably between 1920 and 1929. Year-on-year growth rates oscillate around the zero percent line. ${ }^{13}$

Thus, the analysis of both dimensions of income distribution becomes particularly important in the context of a constant wage share and a pronounced consumption boom as a stagnating wage share leaves us with the question of why households increased their consumption expenditures when wages did not rise accordingly. Thus, the question to be answered in the next sections is whether traditional consumption theories can account for the surge in household debt or the decline in household saving rates during times of rising inequality.

12. The simultaneous rise of top income shares and flat wage shares is one of the most striking parallels between the Great Depression and the Great Recession; see Belabed et al. (2013). One of the potential explanations for this phenomenon is the so-called 'winner-take-all' hypothesis (Frank/Cook 2010). According to this explanation, relatively small differences in skills can lead to extraordinarily large gains in income. The result is a stabilization of the wage share despite significant wage losses of middle- and lower-income groups.

13. Notwithstanding the facts mentioned above, in some industries the income share of labor may have increased (see, for instance, Keller 1973). 


\subsection{Household consumption, saving, and debt}

The 1920s were one of the most innovative periods in the twentieth century. The main innovations included radio sets, dynamic loudspeakers, TV systems, commercial air travel, and, probably less important, the first 3D movie (Feinstein et al. 2008: 75). Consumer durable goods were made available to millions of households through increased automatization of the production process and the rise of the credit industry. Consumption expenditures for durable goods increased significantly during the 1920s, as can be seen in Figure 4. While consumption expenditures for perishable goods declined significantly after the war, expenditures for durable goods such as cars, refrigerators, and TV and radio sets increased during the 1920s. For instance, the index of production of durable goods provided by the Federal Reserve Bank of St. Louis rose from 82 points in 1919 to 119 points in 1929. Factory sales of passenger cars increased from 1.6 million cars to 4.5 million cars between 1919 and 1929 (Carter et al. 2006: table Df343-346). ${ }^{14}$ Towards the end of the decade, households spent almost 7 percent of disposable personal income on major durable goods, more than 13 percent on semi-durable goods, around 4 percent on minor durable goods, and almost 40 percent on services. Expenditures on perishable goods, however, declined from around 40 percent around the end of the nineteenth century to less than 35 percent at the end of the 1920s. At the same time, the saving rate of households declined dramatically from around 7 percent before the war to 1.2 percent at the

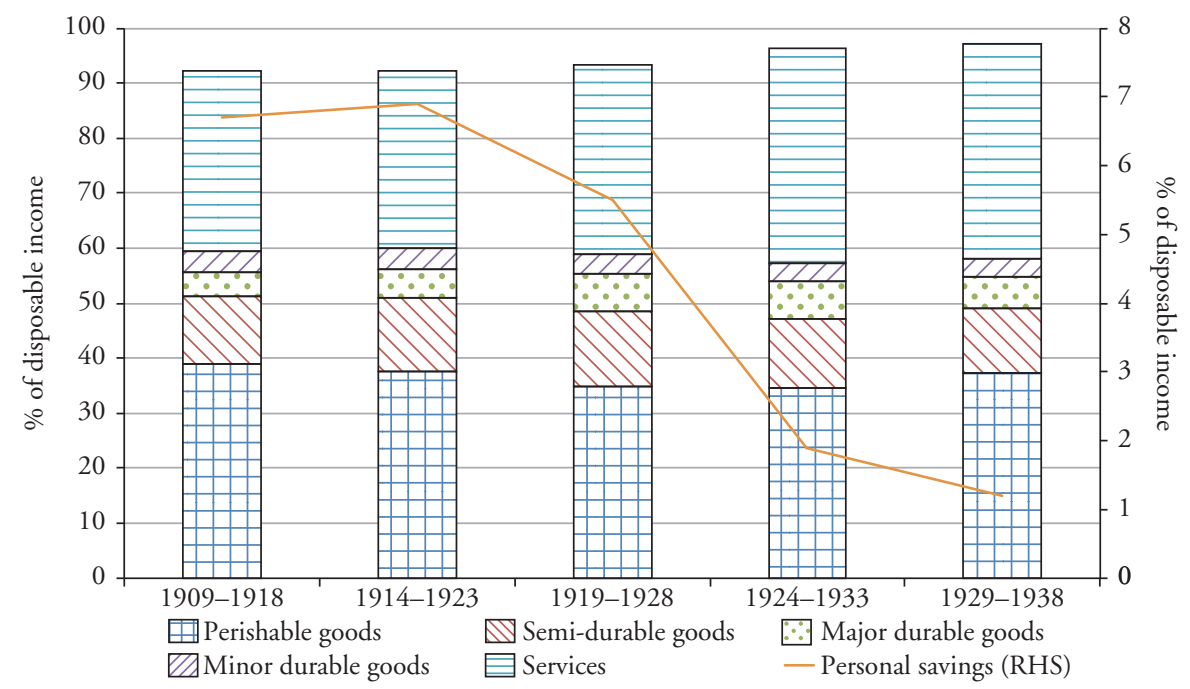

Source: Olney (1991: table 2.8).

Figure 4 Expenditures on goods and services and personal saving rate (as percentage of disposable income), decade averages

14. As impressive as the number of sold cars is by itself, the spread of passenger cars to almost every household had far-reaching effects. Urbanization would not be possible without widely available private transport opportunities which, in turn, led to increasing demand for housing in the suburbs of the cities. Certainly, other industries, such as rubber, tires, oil, or road construction benefited from the car boom as well. 
end of the 1920s. This constitutes the most significant decline in household saving since the start of the series in 1869. Furthermore, household saving, as a share of disposable income, would not be as low for the next 75 years.

Simultaneously, consumer debt increased at a remarkable pace during the 1920s, in absolute terms and as a share of disposable income. Although consumer debt outstanding showed an upward trend before the 1920s, it is obvious from Figure 5 that the pace of debt accumulation increased during the period of interest. Outstanding consumer debt doubled between 1920 and 1929 and peaked at around \$7.6 billion in 1929, which constitutes an unprecedented rise in consumer debt. Even more impressive is the increase of the consumer debt-income ratio which also doubled between 1920 (4.6 percent) and 1929 (9.3 percent). Though the levels of consumer debt and the debt-income ratios seem negligible from today's point of view, it is important to note two aspects. First, major institutional changes have taken place in the 1920s, so that even relatively moderate levels of consumer debt may have contributed to financial fragility. Second, consumer debt is only one measure of household debt; the other one is mortgage debt. During the 1920s there was a pronounced housing bubble which peaked around 1925. Figure 6 presents data on privately owned, non-farm housing units started and nominal home prices indexed for 1915. Housing units started increased by a factor of nine between 1918 (the trough) and 1925 (the peak). From the beginning of the series in 1915, the increase is still remarkable: housing units started more than doubled in only 10 years. At the same time, nominal home prices increased by 50 percent between 1915 and 1925. The real-estate bubble of the 1920s was highly debt-financed, which in turn was securitized and sold on newly emerging

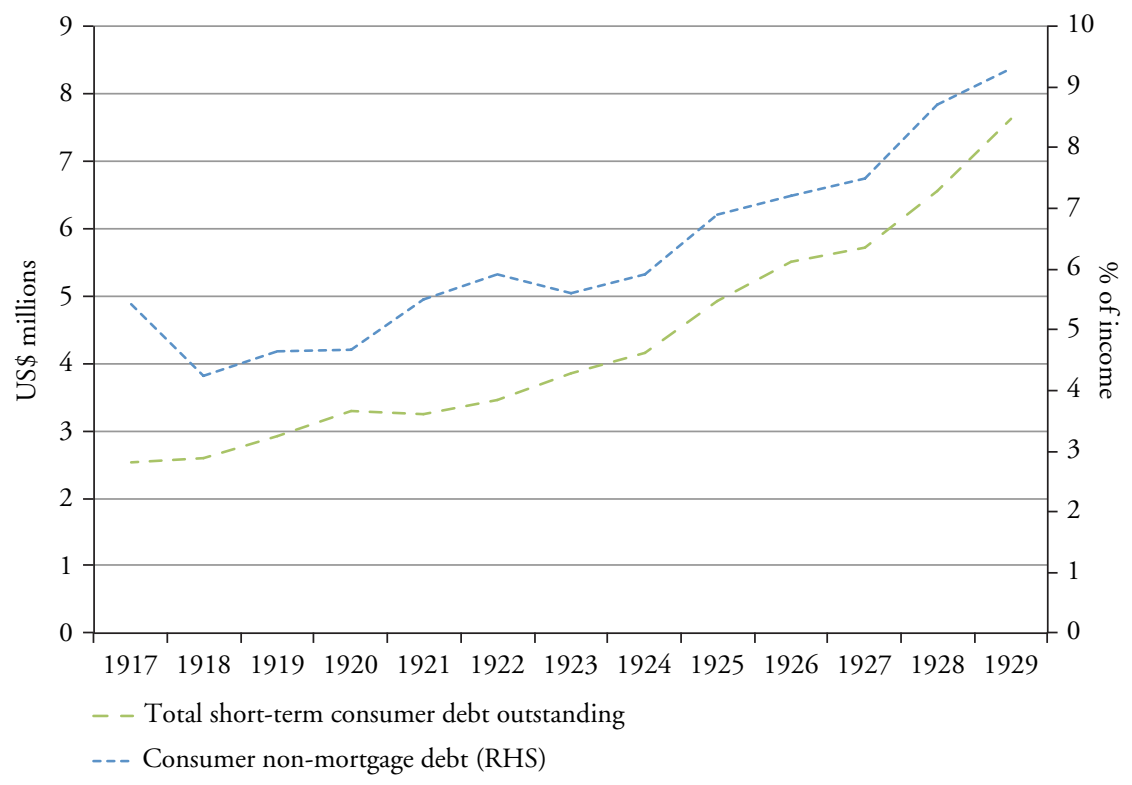

Sources: Goldsmith (1955: table D-1); Olney (1991: table 4-1).

Figure 5 Total short-term consumer debt and consumer non-mortgage debt as percentage of income, 1917-1929 


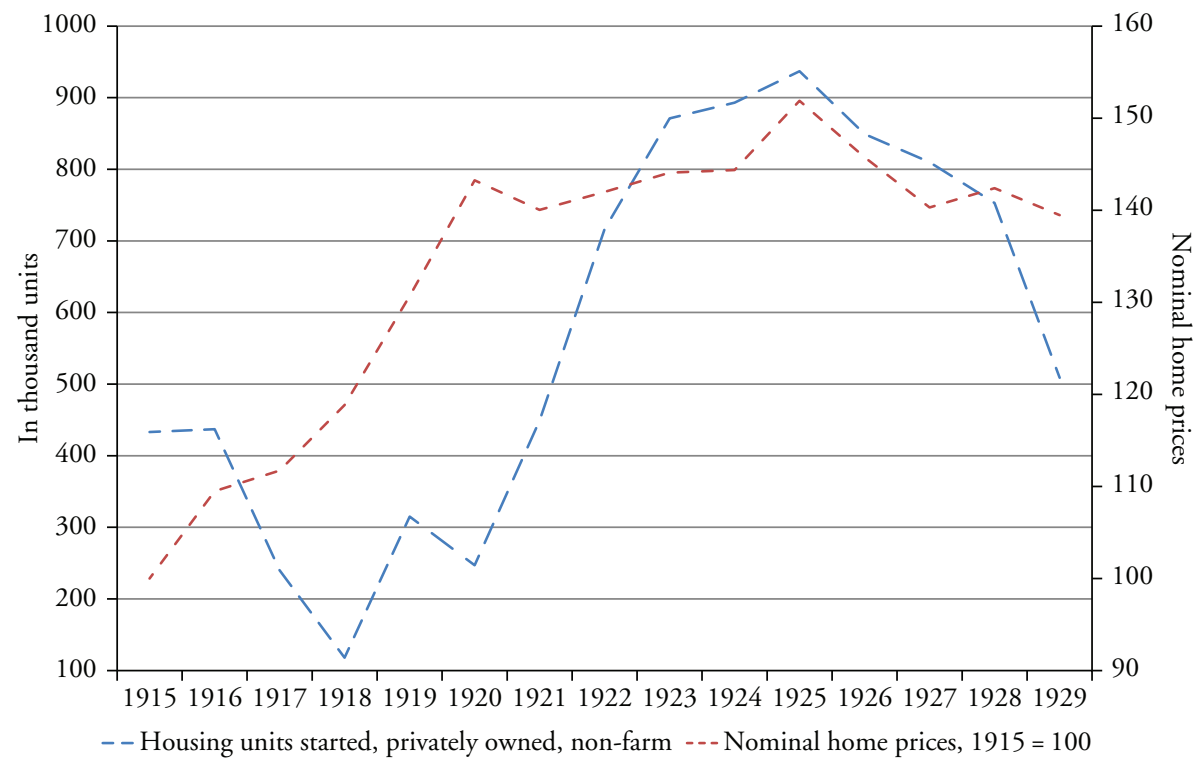

Sources: Carter et al. (2006: table Dc510-530); Grebler et al. (1956).

Figure 6 Housing units started (privately owned, non-farm) and nominal home prices, 1915-1929

markets for securitized debt. ${ }^{15}$ Figure 7 presents total non-farm residential mortgage debt in absolute values and as a share of total wealth. Similar to the trends in consumer debt, nonfarm residential mortgage debt did increase before the 1920s, albeit at a much slower pace. Between 1920 and 1929, mortgage debt increased threefold from $\$ 9.1$ billion to $\$ 27$ billion. Simultaneously, the mortgage debt-wealth ratio almost tripled between 1920 (10.2 percent) and 1929 (27.2 percent), so the expansion of mortgage debt was even larger than the residential construction boom itself.

\subsection{Reconciling facts and theory}

This section attempts to reconcile the stylized facts from the previous section by arguing for an application of the relative income hypothesis. Furthermore, the effects on macroeconomic stability will be discussed. According to the relative income hypothesis, households' consumption preferences are interdependent, which is the key innovation compared to the Keynesian consumption theory or more orthodox theories of

15. Due to limitations this paper does not attempt to give a full picture of the 1920s housing bubble, except for debt-related aspects. For a more detailed description of the housing bubble, especially its causes, see White (2009). He also discusses various weaknesses of the standard housing price index such as the Case-Shiller-Index which, from White's point of view, underestimates housing prices during the 1920 s to a significant extent. 


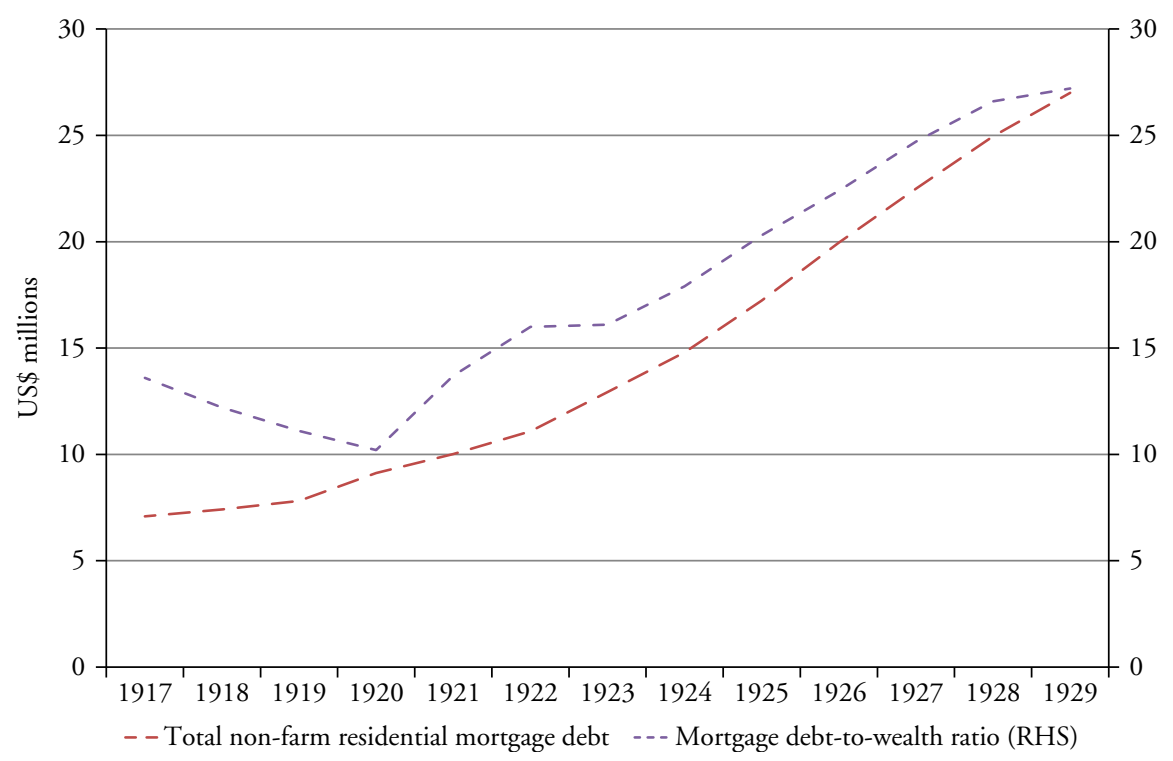

Source: Grebler et al. (1956: tables L-1 and L-6).

Figure 7 Total non-farm residential mortgage debt and as a share of non-farm residential wealth, 1917-1929

consumption (for example, Friedman 1957; Modigliani/Brumberg 1954). ${ }^{16}$ This means that in addition to standard explanatory variables for consumption, such as (permanent) income or (net) wealth, consumption of the household's reference group co-determines the desired level of consumption. Following behavioral insight that status comparisons are predominantly upward-looking, a households reference group is defined as the next-highest household in the income distribution. Whether this desired level of consumption will be realized is not clear a priori. For instance, banks and other lending institutions may refuse to give out loans if the household cannot meet the standards of the lender and the decline of household saving is naturally constrained by the level of income. However, it is safe to assume that lending standards have been relaxed during the 1920s (see Section 4.2).

As was mentioned before, the rise of income inequality was almost entirely due to developments in the distribution of income between households. Furthermore, the growth of income shares was more pronounced towards the upper end of the income distribution. Imagine a household in the ninth decile, that is, belonging to the households just below the very top 10 percent of the population. If income is redistributed upward, especially from lower (and lowest) income groups to the very top, we can safely assume that households in the top decile will increase their consumption, albeit to a lower extent than the

16. Note that, from a methodological point of view, Duesenberry's theory of consumption behavior is grounded in neoclassical economics, that is, utility maximization under constraints. However, this is not a necessary condition. For a Keynesian interpretation see Belabed et al. (2013), where a stock-flow consistent macroeconomic model capturing key insights from the relative income hypothesis is modeled. 
additional income. Due to demonstration effects it is, furthermore, also safe to assume that the top decile will consume more positional goods that reveal their economic and social status. The result is that for lower income groups, especially the group just below the group which experienced a rise in income, the choice is between increasing their consumption expenditures or face a painful loss of relative status. Increasing consumption expenditures to reach the (higher) level of desired consumption can be done through various coping mechanisms (Reich 2010). Households may choose to decrease their savings, increase their demand for credit, increase working hours, increase labor market participation of other household members, or a combination of these. Obviously, households have opted for drawing on their saving, which is perfectly compatible with the relative income hypothesis, not with Keynesian consumption theory. Remember that in a purely Keynesian world, an upward redistribution of income should, ceteris paribus, lead to an increase in savings due to the lower marginal propensity to consume of high-income households and, therefore, to weak aggregate demand. Furthermore, households were increasingly able and willing to finance consumption expenditures through consumer or mortgage debt (see Figures 6 and 7). Indeed, the 1920s was an exceptional period with respect to private debt. Fackler/Parker (2005: 70) argue 'that the 1920s is the leading candidate for a period of nominal over-indebtedness' (emphasis in original). Furthermore, none of the following decades (until 1975) had a higher debt-income ratio at either its start or its end. And none has seen higher growth rates than the 1920s (Fackler/Parker 2005).

At the household level, the inflation of asset prices such as houses, land, or securities improves the balance sheet of households, which allows for increasing the liabilities side of their balance sheet. However, as soon as the value of assets declines, the balance sheet of households deteriorates as the value of liabilities (and the contractual debt service obligations) remains unchanged in the balance sheet. Households and other economic actors in this situation will turn into debt minimizers, using all remaining cash flows to restore their balance sheet (Koo 2009; Mishkin 1978). The effects of this debt-deleveraging process become more pronounced the more households are indebted and if other sectors, such as the corporate sector or the banking sector, have gone into debt as well. One crucial ingredient for a crisis like the Great Depression, however, is rapid and comprehensive innovation and deregulation of financial markets and broad institutional change.

\section{INSTITUTIONAL CHANGE AND FINANCIAL INNOVATION DURING} THE 1920s

The change of institutions, whether societal or particular market institutions, is a crucial determinant of whether a debt-financed consumption-driven growth regime evolves. The surge in financial innovation enabled households to take out loans to finance increased expenditure for (durable) goods or residential real estate. This section presents evidence on institutional change in the following ways. First, financial innovation in the banking sector was at the forefront of institutional change when regular commercial banks transformed themselves into investment banks (Krooss/Blyn 1971), which was at least partly inspired by the banking sector losing its share in the corporate loan market to the stock market. Hence, this section comprises data on developments in the stock market as well (for example, the Dow Jones Industrial Index, trade volumes on the stock exchange, and types of shares issued on the stock exchange). In addition, data on brokers' loans are included to emphasize the degree of speculation on the New York Stock Exchange during the 1920s. Second, to describe developments on household credit markets, the paper discusses installment credit and the emergence of sales finance agencies 
which helped fuel the durable goods consumption boom of the 1920s. In addition, the mortgage market is discussed by presenting descriptive evidence on the growth of mortgage debt coupled with the advent of mortgage securitization. Third, the change of attitudes of households toward credit and debt as well as the increasing importance of advertising and marketing techniques is discussed. Both may aggravate the demand for household debt already fueled by the household sector's wish to keep up with their peers.

\subsection{The stock market}

Without any doubt, the 1920s were an unprecedented era of financial innovation and structural change, for example when commercial banks increasingly assumed fiduciary functions and transformed themselves into investment banks (Krooss/Blyn 1971). ${ }^{17}$ The transformation of banks into investment banks was, in part, inspired by corporations increasingly issuing equity to finance new investment instead of traditional external financing, that is, loans from banks. Figure 8 shows the stocks sold on the New York Stock Exchange, the major financial hub of the US, then and now. Between 1919 and 1929 the number of shares sold more than quadrupled. Moreover, whereas the housing boom stopped around 1925, the stock-market boom gained pace toward the end of the decade. Between 1927 and 1929 alone, the number of shares sold almost doubled. In order to offset the losses of the credit business with firms, commercial banks began doing business in the stock market and, later on, in even riskier security markets. This was undoubtedly accentuated by the public's increasing mania for securities toward the end of the 1920s (ibid.). These numbers, however, do not provide information on newly issued equity on the stock market. In fact, they include both shares already issued and newly issued shares. Figure 9 provides data on newly issued corporate capital. Although there was some growth between 1921 and 1927, the graph shows a rather remarkable increase in firms' stock-market activity from 1927 on. The value of common stock between 1927 and 1929 increased from \$500 million to more than $\$ 4.5$ billion, which constitutes an increase by a factor of nine. The value of newly issued preferred stock increased by a smaller magnitude, though still significant enough. Between 1927 and 1929, the value of preferred stock rose by a factor of three. What this all amounts to is that there is ample evidence for firms turning to the stock market to finance their activities instead of taking out new loans from banks.

Another significant component of financial market innovation on the stock market was the rise of brokers' loans during the 1920s and especially toward the end of the decade. A broker's loan is a loan from a bank to a professional broker who finances a margin account for investors who seek to buy securities or commodities with the money granted. The investor is, thus, participating in the securities or commodities market with the broker's money or leveraging his financial investment. A rise in the total amount of brokers' loans indicates a higher willingness of investors to speculate in financial markets. Between 1918 and 1929 , brokers' loans increased by a factor of four from $\$ 1$ billion to more than $\$ 4$ billion (Carter et al. 2006: table Cj866-869). As a share of GDP, brokers' loans increased by a factor of seven between 1918 and 1928. At the same time, the DJIA rose from 107.23 points in 1919 to 248.5 points in 1929 (see Figure 8). The latter

17. It was exactly this transformation of commercial banks into investment banks that later inspired the passage of the Banking Act of 1933, better known as the Glass-Steagall Act. It required banks to separate their usual business of deposits and loans from trading with securities. Glass-Steagall was repealed in 1999, effectively contributing to the second transformation of commercial banks and insurances into some kind of investment banks. 


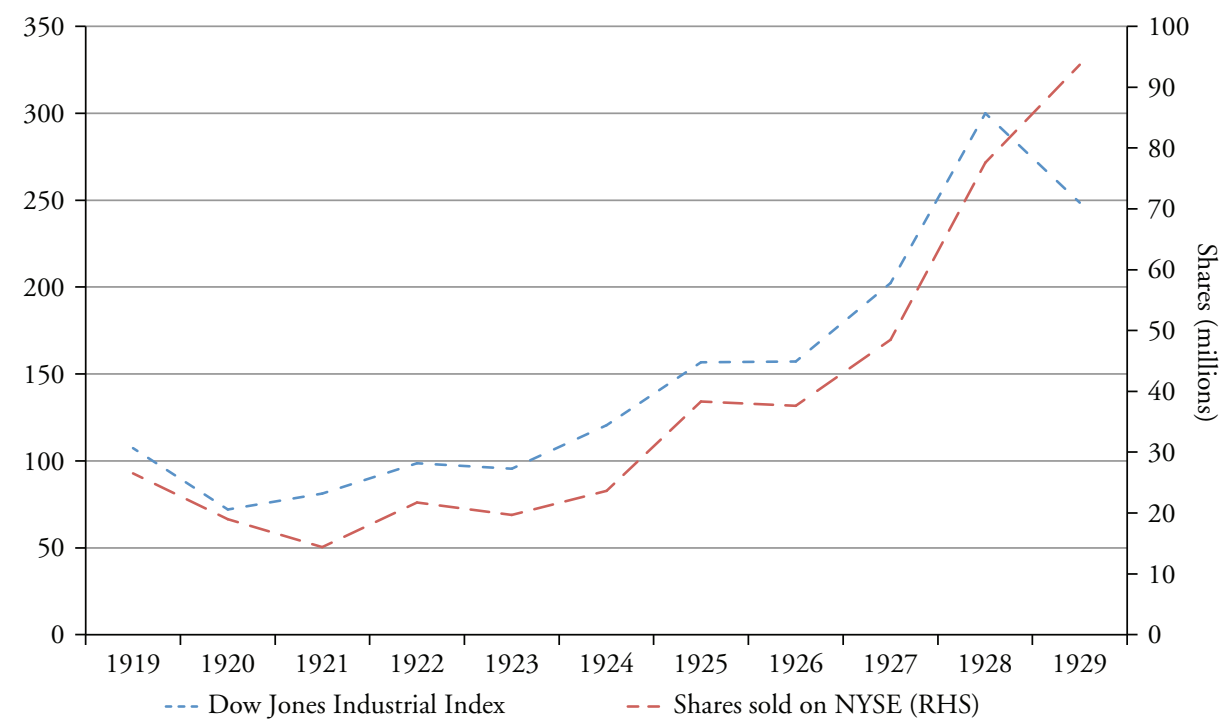

Source: Carter et al. (2006: tables Cb52-54 and Cb797-807).

Figure 8 Shares sold on New York Stock Exchange and Dow Jones Industrial Average Index, 1919-1929

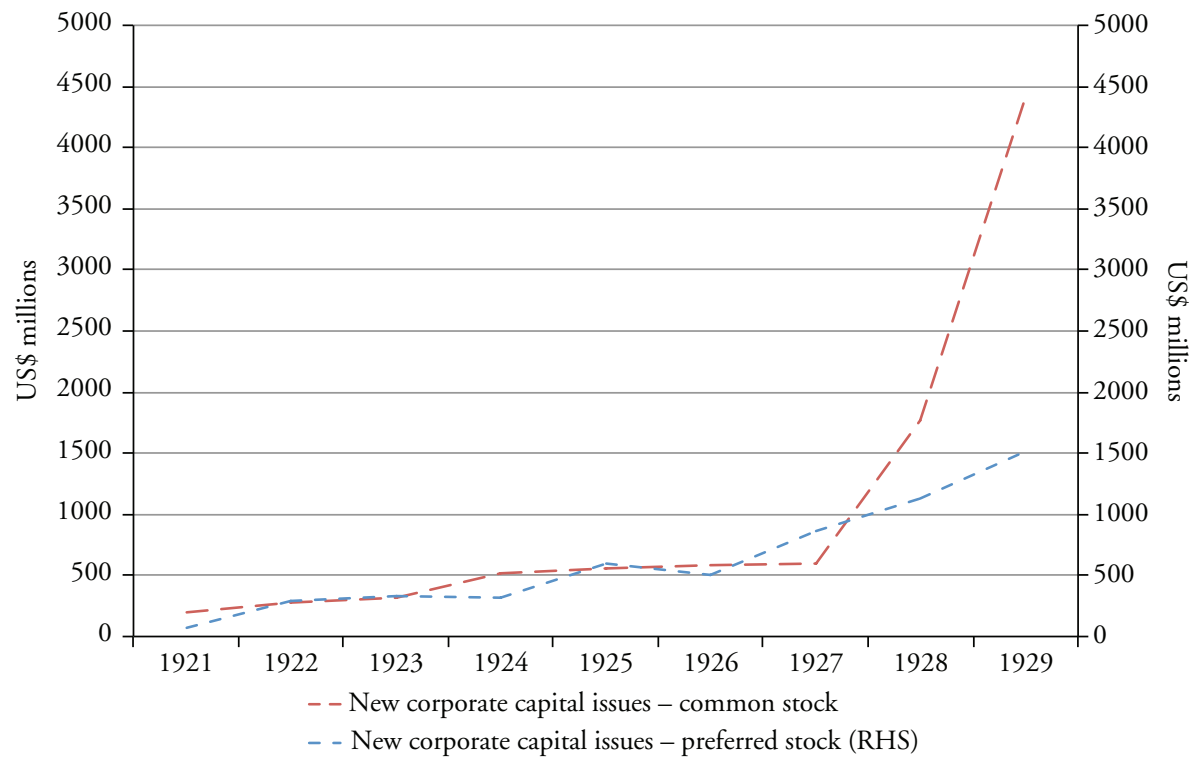

Source: US Department of Commerce (1930: table 315).

Figure 9 New corporate capital issued; common and preferred stock, 1921-1929 
number camouflages the speculative excess because of the inclusion of the stock-market crash in October 1929 - the DJIA leveled off at 300 points in 1928 (ibid.: table Cj797-807). Certainly, the increase of the DJIA also reflects the economic expansion of the 1920s, the so-called fundamentals. However, it is commonly accepted that speculation was vibrant at least during the last 2 years before the stock market crash of 1929. Shares sold on the New York Stock Exchange (NYSE) increased from an annual average of 26 million shares in 1919 to more than 93 million shares in 1929 (ibid.: table Cb52-54).

\subsection{Household credit markets}

With respect to institutional changes in the credit market for households and consumers we focus on three key aspects: first, on the rise of consumer installment selling, which is a special form of consumer credit, and the simultaneous emergence of sales finance agencies, which largely took over the installment credit business from sellers and manufacturers; second, on the rise of mortgage financing; and, finally, on the evolution of markets for mortgage securitization.

The 1920s mark the advent of installment credit and the evolution of sales finance agencies. Seligman (1927) defines installment credit as a transfer of wealth for which the payment is deferred (at least partly) to the future. ${ }^{18}$ Usually, households pay down a percentage of the good's price and pay the rest in monthly (or other regular) installments. For the producer, installment selling was a crucial innovation for market expansion as it enabled him to reach consumers who were not able to either pay the full price cash down or a lump sum after a reasonable period of time. For the consumer, installment selling cleared the way to purchasing goods which were not affordable such as cars, refrigerators, TV sets, and so on. Installment selling, however, was not only restricted to the sales of goods to individuals. It was also used to acquire real estates and, to a lesser extent, for production purposes. The focus here is on installment selling to households. Nominal installment debt was $\$ 1.8$ million in 1919 and climbed to $\$ 4.9$ million by 1929 (Olney 1999) and the automobile was at the center of installment selling. In 1919, 1.65 million cars were sold and the number increased to 4.46 million in 1929 (Carter et al. 2006: table Df343-346). Olney (1999) reports that in 1929 nearly a quarter of households bought a car, and 15 percent of households bought a car in installments, up from 4.9 percent in 1919. Including sales of used cars, more than 7 million cars were sold in 1929; in 1919 merely 2 million cars were sold. Before the 1920 s, installment selling was mostly operated by producers and sellers. After the war, installment credit was increasingly operated by sales finance agencies. These financial corporations operate in the following way. A car dealer, for instance, was required to pay for the stock of cars cash down. Certainly, most dealers did not have the means to pay for their stock of cars immediately. Banks, on the other hand, refused to grant loans to dealers. Hence there was need for a new mechanism of intermediation between dealers and producers which was provided by sales finance agencies. In 1916, there were six finance companies in the car installment business; by 1929 more than 1000 sales finance companies were in business, although the 'big four,' GMAC, CCC, CIT, and Universal, dominated the installment business in the 1920s and 1930s. Total outstanding automobile securitized loans increased fivefold between 1919 and 1929, whereas securitized loans on other consumer goods (such as TV sets, radios, etc.) increased by

18. All data in this paragraph on installment credit are from Seligman (1927) unless stated otherwise. 
a factor of three in the same period. Overall, the consumer durable goods revolution in the 1920s would most certainly not have assumed these dimensions without the innovation of installment credit (Olney 1991).

A second important feature of the 1920s debt revolution was the unprecedented increase in the mortgage financing of commercial and residential structures and the evolution of mortgage securitization markets. Snowden (2010) reports that four intermediaries were the key actors in the 1920s mortgage business: commercial banks, life insurance companies, mutual savings banks, and Building \& Loans (B\&Ls). Although the former three intermediaries accounted for $\$ 6.6$ billion of new investment, this only represented a third of the total expansion of residential mortgage debt during the 1920s. The remaining two-thirds were financed by $\mathrm{B} \& \mathrm{~L}$ corporations or non-institutional investors amounting to more than $\$ 12$ billion of new investment. The B\&L sector increased by the number of customers, assets, and institutions, the latter increasing from 8000 in 1919 to 13000 in 1927 (Bodfish 1931 via Snowden 2010). During the 1920s, B\&Ls 'became leaders in developing affordable, low-down payment loans [and] by the end of the 1920s they wrote more mortgage debt on one-to-four-family homes each year than life insurance companies, commercial banks and mutual savings banks combined' (Snowden 2010: 10). ${ }^{19}$

Finally, the securitization of mortgage debt - creating marketable securities investors could buy - was soon to follow. Mortgage insurance companies and real-estate bond houses issued different, but essentially similar, securities based on mortgage-financed commercial or residential property. The market grew rapidly in the 1920s; by 1930, 50 mortgage insurance companies were active in New York alone, originating and marketing securities written on $\$ 3$ billion of mortgage debt (Snowden 2010). The market for real-estate bonds increased rapidly too. By 1929 more than $\$ 6$ billion (of which $\$ 2.4$ billion concern residential property) of real-estate bonds were outstanding - a rise of more than $\$ 5.6$ billion or almost 1200 percent in 10 years (Grebler et al. 1956: table L-2).

The rapid growth of the consumer durables industry would have not materialized without the simultaneous expansion of household debt. This expansion itself is based on the unprecedented innovation in financial markets, for example the emergence of sales finance agencies or the securitization of debt obligations. All these factors have led to an increased importance of the financial sector. Figure 10 presents various measures of financial sector income (including insurance and real estate). The income share of finance (in percent of GDP) increased from below 3 percent of GDP to almost 4.7 percent of GDP, a level unreached again until the late $1970 \mathrm{~s}^{20} \mathrm{~A}$ similar trend is observed for different measures of GDP, excluding defense expenditures or net exports of financial services from GDP. Another important measure is compensation in finance, insurance, and real estate as a share of total compensation (wages and salaries). Compensation in finance increased from 3.3 percent in 1919 to 5.3 percent in 1928 , an increase of 61 percent in just 10 years.

\subsection{Changing attitudes and advertising}

Furthermore, societal attitudes towards consumer credit changed considerably, as did advertising and marketing techniques (Olney 1991). The effect of the former was an increased demand for credit, whereas the latter dramatically expanded the circle of peers with which households were able to compare themselves.

19. Data on B\&Ls can be found in Grebler et al. (1956: table N-13).

20. For a longer series than presented here, the reader is referred to Philippon (2015), who provides data through to 2009 . 


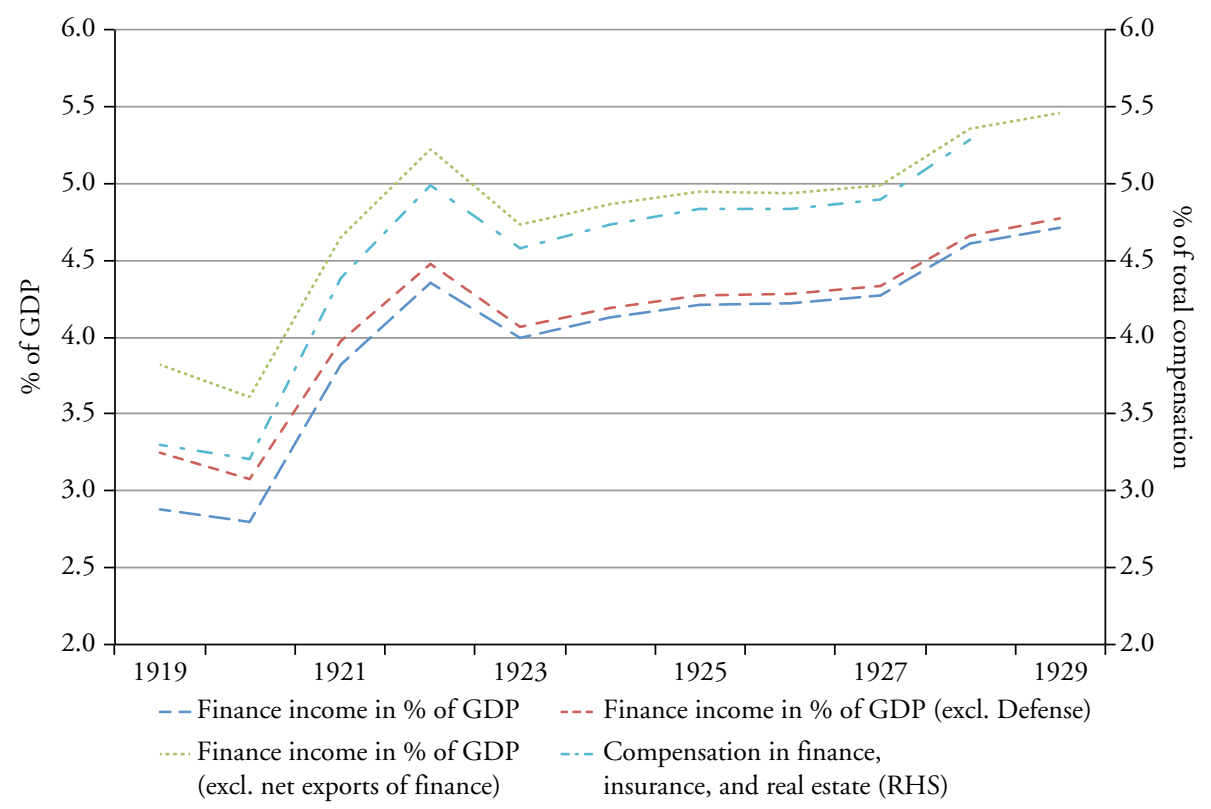

Source: Philippon (2015).

Figure 10 Finance income as a percentage of GDP (various measures) and compensation in finance, insurance, and real estate as a share of aggregate compensation, 1919-1929

None of these developments in the financial sector would have had that great an impact without a fundamental change of societal attitudes toward credit and debt, sometimes fueled by more aggressive and manipulative methods of advertising and marketing. According to Seligman (1927), 'the purchasing public was gradually accustoming itself to pay for the cars ... in successive installments, chiefly in monthly payments.' Similarly, Olney (2002: 2) wrote that families or individuals '[o]nce characterized as spendthrifts who could not be trusted to repay their debts and who therefore required the threat of stringent default penalties to force adherence to a credit contract, by 1929 ... were sophisticated borrowers taking advantage of the opportunity to "buy now, pay later".'

Advertising, on the other hand, became significantly more important to sellers during the 1920s. Greater availability of credit made expensive products readily available for many households (though not all), whereas advertising rendered these products desirable (Olney 1991). Not surprisingly, total advertising expenditures for advertising in print media undoubtedly increased during the $1920 \mathrm{~s} .{ }^{21}$ Another medium for placing ads was the radio. According to the Public Broadcasting Service (PBS), the first ad to air on

21. See Olney (1991: table 5.1), who uses various sources to show that advertising expenditures exploded during the 1920s. For instance, estimates of Printers' Ink increased from $\$ 2.3$ billion in 1919 to $\$ 3.4$ billion in 1929; Pope's estimates more than double from $\$ 1.4$ billion to $\$ 2.9$ billion in the same period. Olney (ibid.) also reports that the size of advertisements increased during the 1920 s and that advertisements, in general, became more manipulative and less informational. 
radio for a real-estate developer in New York City was aired in $1922 .{ }^{22}$ Local networks soon became big business and radio broadcasting developed further during the 1920s. For instance, 12 million people had access to a radio in 1930, and more than 50 percent of families owned a radio set in the large urban areas of New York, Illinois, or California. ${ }^{23}$ The widespread distribution of radios during the 1920s, often bought on installment, meant that mass consumerism sparked mass communication, which further fueled mass consumerism through broadcasting of advertisements for new products or new financial possibilities to obtain these products. Summarizing, societal changes of attitudes towards debt-financed consumption and new advertising techniques and possibilities facilitated the evolution of a debt-financed consumer-durable goods revolution during the 1920s.

\section{CONCLUDING REMARKS}

This paper has shown that the 1920s were a period of rising top-end inequality in the United States. The rise of top income shares leveled off only in 1929, just before the onset of the Great Depression. In addition, household debt rose to unprecedented levels and, simultaneously, personal saving declined to historical lows. Furthermore, it suggests that these trends can be explained by applying a non-standard consumption theory, the relative income hypothesis, to the United States during the 1920s. Households who do not experience a rise in relative incomes face a trade-off between keeping up with the consumption norms of their peer groups or a painful loss of relative status. Given the decline in saving rates and the increase in household debt, both perfectly compatible with the relative income hypothesis, households obviously chose to keep up with their peers. As a result, private consumption remained high but at the cost of an unsustainable credit bubble, which was allowed to develop after fundamental institutional changes on financial markets but also in a broader context. Financial innovation enabled commercial banks to transform themselves into investment banks. Consumer installment and mortgage debt exploded during the 1920s in the US and financial innovation, such as securitization, enabled financial institutions to issue ever more debt to households and sell it to investors. In addition, households' attitudes towards credit and debt-financed consumption appear to have changed along with new and more aggressive methods of advertising for consumer goods and methods of financing. However, after the onset of the Great Depression, households were left with rising real debt in the context of severe deflation and a massive decline of their assets' value. In this sense, the narrative developed here is also compatible with the balance-sheet recession view of Koo (2009) and Mishkin (1978) or the debt-deflation theory of Fisher (1933).

Of course, this study does not rule out other possible causes of the Great Depression in the United States or internationally. Indeed, given the magnitude and length of the crisis, it would be most peculiar to rely solely on a mono-causal line of argument. This paper merely attempts to add another piece to the bigger picture by shedding light on the behavior of the household sector during the 1920s in the United States, a period of rising topend income inequality, household debt, and macroeconomic and financial instability. For instance, the role of the Gold Standard is certainly one of the main culprits in explaining the extreme depth and length of the Great Depression of the 1930s. Other approaches emphasize the role of policy mistakes of the Federal Reserve before and during the

22. Information available at: http://www.pbs.org/wgbh/aso/databank/entries/dt20ra.html.

23. See Bureau of the Census online, available at: http://www.census.gov/newsroom/releases/ archives/census_2000/cb02-cn62.html, for data on how many people had access to radio; and http://www.census.gov/geo/maps-data/maps/pdfs/thematic/radios.pdf, for the distribution of ownership of radio sets by states in 1930 . 
Great Depression (Friedman/Schwartz 1963). In addition, data limitations, most importantly decile-specific data on consumption, saving, and debt, considerably limit the depth of this study. For instance, although aggregate data on personal saving is readily available, to the best of our knowledge, there is no reliable disaggregated data on personal saving. The same is true for data on consumption or household debt. These limitations, however, point to possible paths for future research on the topic once this data becomes available. More consolidated aggregate data, together with reliable data at the household level, would most certainly be helpful in further investigating the role of income inequality before the Great Depression. In addition, and perhaps in a more subtle way, the paper argues in favor of enriching current economic theory by including sociological aspects (for example, status comparisons), the institutional environment (for example, financial markets, but also in a broader definition such as the general attitudes within society toward debt or other variables), and economic history. From this point of view, it seems, there is need for a more nuanced view of the current economic and financial crisis, at least for some countries such as the US or the UK, where private debt mattered much more in the period leading to the current crisis than public debt. Hence, understanding the drivers of private debt from a broader perspective compared to standard inter-temporal consumption smoothing is crucial for understanding the evolution of debt-driven consumption booms ultimately leading to financial and economic crises.

\section{REFERENCES}

Almunia, M., Bénétrix, A., Eichengreen, B., O’Rourke, K.H., Rua, G. (2010): From Great Depression to Great Credit Crisis: similarities, differences and lessons, in: Economic Policy, 25(4), 219-265.

Atkinson, A.B., Morelli, S. (2011): Economic crises and inequality, Human Development Research Papers (2009 to present) HDRP-2011-06, Human Development Report Office (HDRO): United Nations Development Programme (UNDP).

Behringer, J., van Treeck, T. (2013): Income distribution and current account: a sectoral perspective, IMK Working Paper 125-2013, IMK at the Hans Boeckler Foundation, Macroeconomic Policy Institute.

Belabed, C.A., Theobald, T., van Treeck, T. (2013): Income distribution and current account imbalances, Working Paper 126, IMK.

Bernanke, B.S. (2000): Essays on the Great Depression, Princeton, NJ: Princeton University Press.

Bertrand, M., Morse, A. (2013): Trickle-down consumption, NBER Working Paper 18883, NBER.

Bleaney, M.F. (1976): Underconsumption Theories, London: Lawrence and Wishart.

Bodfish, H.M. (1931): History of Building and Loan in the United States, Chicago: United States Building and Loan League.

Bordo, M.D., James, H. (2009): The Great Depression analogy, NBER Working Paper 15584, NBER.

Brown, C. (1997): Consumer credit and the propensity to consume: evidence from 1930, in: Journal of Post Keynesian Economics, 19(4), 617-638.

Carter, S.B., Gartner, S.S., Haines, M.R., Olmstead, A.L., Sutch, R., Wright, G. (eds) (2006): Historical Statistics of the United States, Cambridge, UK: Cambridge University Press.

Christen, M., Morgan, R. (2005): Keeping up with the Joneses: analyzing the effect of income inequality on consumer borrowing, in: Quantitative Marketing and Economics, 3(2), 145-173.

Cole, H.L., Ohanian, L.E. (1999): The Great Depression in the United States from a neoclassical perspective, in: Federal Reserve Bank Minneapolis Quarterly Review, 23(1), 2-24.

Cole, H.L., Ohanian, L.E. (2000): Re-examining the contributions of money and banking shocks to the U.S. Great Depression, Staff Report 270, Federal Reserve Bank of Minneapolis.

Cole, H.L., Ohanian, L.E. (2004): New deal policies and the persistence of the Great Depression: a general equilibrium analysis, in: The Journal of Political Economy, 112(4), 779-816. 
Cole, H.L., Ohanian, L.E., Leung, R. (2005): Deflation and the International Great Depression: a productivity puzzle, NBER Working Paper 11237, NBER.

Drechsel-Grau, M., Schmid, K.D. (2014): Consumption savings decisions under upward looking comparisons, in: Journal of Economic Behavior \& Organization, 106(C), 254-268.

Duesenberry, J.S. (1949): Income, Saving and the Theory of Consumer Behavior, Cambridge, MA: Harvard University Press.

Eccles, M.S. (1951): Beckoning Frontiers: Public and Personal Recollections, New York: Alfred A. Knopf.

Eggertsson, G.B. (2008): Great expectations and the end of the depression, in: The American Economic Review, 98(4), 1476-1516.

Eggertsson, G.B. (2012): Was the new deal contractionary?, in: The American Economic Review, 102(1), 524-555.

Fackler, J.S., Parker, R.E. (2005): Was debt deflation operative during the Great Depression?, in: Economic Inquiry, Western Economic Association International, 43(1), 67-78.

Feinstein, C.H., Temin, P., Toniolo, G. (2008): The World Economy between the World Wars, New York: Oxford University Press.

Fisher, I. (1933): The debt-deflation theory of great depressions, in: Econometrica, 1(4), 337-357.

Frank, R.H., Cook, P.J. (2010): The Winner-Take-All Society: Why the Few at the Top Get So Much More Than the Rest of $U s$, New York: Penguin Books.

Frank, R.H., Levine, A.S., Dijk, O. (2014): Expenditure cascades, in: Review of Behavioral Economics, $1(1-2), 55-73$.

Friedman, M. (1957): A Theory of the Consumption Function, Princeton, NJ: Princeton University Press.

Friedman, M., Schwartz, A.J. (1963): A Monetary History of the United States, 1867-1960, Cambridge, MA: NBER.

Galbraith, J.K. (2009): The Great Crash 1929, Boston: Houghton Mifflin Harcourt.

Goldsmith, R.W. (1955): A Study of Saving in the United States, Princeton, NJ: Princeton University Press.

Grebler, L., Blank, D.M., Winnick, L. (1956): Capital Formation in Residential Real Estate: Trends and Prospects, Cambridge, MA: NBER.

Hobson, J.A. (1909): The Industrial System: An Inquiry into Earned and Unearned Income, London: Longmans, Green, and Co.

IMF (2012): World Economic Outlook: Growth Resuming, Dangers Remain, World Economic Outlook 04-2012, Washington, DC: IMF.

Jordà, Ò., Schularick, M., Taylor, A.M. (2013): When credit bites back, in: Journal of Money, Credit and Banking, 45(s2), 3-28.

Jordà, Ò., Schularick, M., Taylor, A.M. (2015): Leveraged bubbles, in: Journal of Monetary Economics, 76, S1-S20.

Kaldor, N. (1966): Marginal productivity and the macro-economic theories of distribution, in: Review of Economic Studies, 33(4), 309-319.

Kalecki, M. (1954): Theory of Economic Dynamics: An Essay on Cyclical and Long-Run Changes in Capitalist Economy, London: George Allen.

Kapeller, J., Schütz, B. (2014): Debt, boom, bust: a theory of Minsky-Veblen cycles, in: Journal of Post Keynesian Economics, 36(4), 781-814.

Kapeller, J., Schütz, B. (2015): Conspicuous consumption, inequality and debt: the nature of consumption-driven profit-led regimes, in: Metroeconomica, 66(1), 51-70.

Keller, R.R. (1973): Factor income distribution in the United States during the 1920s: a reexamination of fact and theory, in: The Journal of Economic History, 33(1), 252-273.

Keynes, J.M. (1936 [2008]): The General Theory of Employment, Interest and Money, Miami, FL: BN Publishing.

Keynes, J.M. (1939): Mr. Keynes on the distribution of incomes and 'propensity to consume': a reply, in: Review of Economics and Statistics, 21(3), 129.

Kindleberger, C.P. (1986): The World in Depression, 1929-1939, Berkeley, CA: University of California Press.

Kindleberger, C.P., Aliber, R. (2005): Manias, Panics and Crashes: A History of Financial Crises, Hoboken, NJ: John Wiley \& Sons. 
Koo, R. (2009): The Holy Grail of Macroeconomics: Lessons from Japan's Great Recession, Singapore: John Wiley \& Sons.

Krooss, H.E., Blyn, M.R. (1971): A History of Financial Intermediaries, New York: Random House.

Kumhof, M., Rancière, R., Winant, P. (2012): Income inequality and current account imbalances, IMF Working Paper 10/268, International Monetary Fund.

Kumhof, M., Rancière, R., Winant, P. (2015): Inequality, leverage, and crises, in: The American Economic Review, 105(3), 1217-1245.

Kuznets, S. (1937): National Income, 1919-1935, Cambridge, MA: NBER.

Lucas, R.E. (2004): The industrial revolution: past and future, in: The Region, May 2004, URL: https://minneapolisfed.org/publications/the-region/the-industrial-revolution-pastand-future.

Malthus, T. (1820): Principles of Political Economy Considered with a View to their Practical Application, London: John Murray.

Mishkin, F.S. (1978): The household balance sheet and the Great Depression, in: The Journal of Economic History, 38(4), 918-937.

Modigliani, F., Brumberg, R. (1954): Utility analysis and the consumption function: an interpretation of cross-section data, in: Kurihara, K.K. (ed.), Post-Keynesian Economics, New Brunswick, NJ: Rutgers University Press.

Olney, M.L. (1991): Buy Now, Pay Later: Advertising, Credit and Consumer Durables in the 1920s, Chapel Hill, NC: University of North Carolina Press.

Olney, M.L. (1999): Avoiding default: the role of credit in the consumption collapse of 1930, in: The Quarterly Journal of Economics, 114(1), 319-335.

Olney, M.L. (2002): Spendthrift, or sophisticated borrower? Institutional response to the twentieth century evolution of consumer credit, in: Proceedings of the Conference on Credit, Trust, and Calculation, 12-14.

Palley, T. (2010): The relative permanent income theory of consumption: a synthetic KeynesDuesenberry-Friedman model, in: Review of Political Economy, 22(1), 41-56.

Philippon, T. (2015): Has the US finance industry become less efficient? On the theory and measurement of financial intermediation, in: The American Economic Review, 105(4), 1408-1438.

Piketty, T. (2014): Capital in the Twenty-First Century, Cambridge, MA: Harvard University Press.

Rajan, R.G. (2010): Fault Lines: How Hidden Fractures still Threaten the World Economy, Princeton, NJ: Princeton University Press.

Reich, R.B. (2010): Aftershock: The Next Economy and America's Future, New York: Vintage Books.

Romer, C.D. (1990): The Great Crash and the onset of the Great Depression, in: The Quarterly Journal of Economics, 105(3), 597-624.

Romer, C.D. (1992): What ended the Great Depression?, in: The Journal of Economic History, 52(4), $757-784$.

Romer, C.D. (1993): The nation in depression, in: Journal of Economic Perspectives, 7(2), 19-39.

Seligman, E.R.A. (1927): The Economics of Instalment Selling: A Study in Consumers' Credit, with Special Reference to the Automobile, New York: Harper and Brothers.

Snowden, K.A. (2010): The anatomy of a residential mortgage crisis: a look back to the 1930s, NBER Working Paper 16244, NBER.

Temin, P. (1976a): Did Monetary Forces Cause the Great Depression, New York: Norton.

Temin, P. (1976b): Lessons for the present from the Great Depression, in: The American Economic Review, 66, 40-45.

Temin, P. (1989): Lessons from the Great Depression, The Lionel Robbins Lectures for 1989, Cambridge, MA: MIT Press.

Temin, P. (1994): The Great Depression, NBER Historical Paper 62, NBER.

US Department of Commerce (1930): Statistical Abstract of the United States 1930, United States Government Printing Office.

Van Treeck, T. (2014): Did inequality cause the US financial crisis?, in: Journal of Economic Surveys, 28(3), 421-448.

Veblen, T. (1899 [2007]): The Theory of the Leisure Class, Oxford World's Classic, Oxford: Oxford University Press.

White, E.N. (2009): Lessons from the great American real estate boom and bust of the 1920s, NBER Working Paper 15573, NBER. 